\title{
Attempts to identify viruses in rheumatoid synovial cells
}

\author{
MARY NORVAL AND B. P. MARMION \\ From the Department of Bacteriology, Edinburgh University Medical School, Teviot Place, Edinburgh EH8 9 AG
}

\begin{abstract}
Norval, M., and Marmion, B. P. (1976). Annals of the Rheumatic Diseases, 35, 106-113. Attempts to identify viruses in rheumatoid synovial cells. Synovial fibroblast cell strains derived from the synovial membranes of 7 patients with rheumatoid arthritis were examined for the presence of viruses, in particular leucoviruses. Seven similar synovial strains derived from patients with other arthritic conditions were used as a control group. Evidence of the presence of a virus or a viral genome was looked for by several methods of induction followed by ${ }^{3} \mathrm{H}$-uridine labelling of the cultures. In addition, the culture supernatant, after induction and after the synovial strains had been co-cultivated with a variety of cell lines from several species, was assayed for the presence of viral RNA-dependent DNA polymerase activity. The DNA-polymerase activity of the synovial cells themselves was also determined. No evidence was found by any of these techniques to indicate the presence of virus or viral information within the synovial fibroblasts.
\end{abstract}

Some simple methods have been developed to grow synovial cells from rheumatoid and nonrheumatoid synovial membranes (Castor and Fries, 1961). These cells can be passed by trypsinization and propagated through at least 15 subcultures. Various workers have looked at these cultures to find differences between the rheumatoid and nonrheumatoid cells which could indicate some abnormality in the rheumatoid cells (Bartfield, 1965; Smith, 1971; Phillips, 1971; Smith and Hamerman, 1969) and in particular some evidence of viral infection.

Generally the rheumatoid cultures grew more quickly but could not be subcultured as many times as the nonrheumatoid cultures. At the ultrastructural level no differences could be detected (WynneRoberts and Castor, 1972). No nuclear bodies were seen and no cytopathic effect on prolonged cocultivation. However, there were various biochemical differences in the cultures, such as increased hyaluronic acid content of rheumatoid cells and increased acid phosphatase activity. It is known that some viruses can interact with the host cell to alter some cellular metabolic activities; for example, avian sarcoma viruses induce increased hyaluronic acid production in infected chick embryo fibroblasts (Ishimoto, Temin, and Strominger, 1966).

Using conventional virological techniques on rheumatoid synovial fibroblasts, no virus has been

Accepted for publication November 1, 1975. Correspondence to Dr. Mary Norval. isolated after co-cultivation or by Sendai-induced cell fusion, nor did the cells show haemadsorption or haemagglutinins and there was no interference with VSV or ECHO-11 replication (Phillips, 1971). Ford and Oh (1965) reported no virus in the culture supernatant after prolonged incubation and no difference in NDV susceptibility. Smith and Hamerman (1969) also failed to isolate a virus from these cells although they showed a resistance to infection with rubella and NDV in the case of the rheumatoid cells. This has been attributed to the increased hyaluronic acid content of the rheumatoid cells compared to the nonrheumatoid (Clarris, Fraser, and Rodda, 1974; Patterson and others, 1975). However, it has also been shown that two means of transferring this resistance to rubella are by intra-articular injection into rabbit joints whereby the rabbit synovial membrane cells become resistant 2 to 6 months later (Smith and others, 1974), and by Sendai-virus induced cell fusion of these cells with normal rabbit synovial cells (Smith and Hamerman, 1974). No virus was released from these cultures.

It is possible that, should a virus be concerned in the aetiology of rheumatoid arthritis, the infection may be a nonlytic one and thus would not be detectable by normal techniques. There are several possibilities for a persistent viral infection of this kind. The virus might be produced in small numbers and be noncytopathic. Alternatively there might be a defective nonproductive cytoplasmic infection with 
formation of new viral-coded antigens on the cell surface. As a third possibility, the viral genome might be integrated into the host cell genome with some accompanying changes in the cell. In the case of DNA viruses this integration can occur directly; with some RNA viruses, as shown with leucoviruses, a DNA copy of the RNA is made first using RNA-dependent DNA polymerase (reverse transcriptase) before integration occurs. Recently some of the techniques used in leucovirus work have been applied to synovial membranes and strains to ascertain if a virus of this type is present (Norval, Ogilvie, and Marmion, 1975; Spruance and others, 1975).

Person, Sharp, and Rawls (1973) have studied cell cultures from synovial fluids and membranes after co-cultivation with Vero cells and after induction with 5-iododeoxyuridine (IUDR.) ${ }^{3} \mathrm{H}$-uridine or ${ }^{3} \mathrm{H}$-thymidine was added and the culture supernatant subsequently examined by sucrose and caesium chloride density gradient centrifugation to isolate labelled particles. No virus was found. Grayzel (1973) has also described the result of adding ${ }^{3} \mathrm{H}$-uridine to the medium of cultured rheumatoid cells with and without pretreatment with 5-bromodeoxyuridine (BUDR) and actinomycin D. There was no evidence of virus particles being released from the cells or of viral-specific RNA being synthesized within the cells.

In this paper we describe the properties of a collection of synovial fibroblast cell strains from rheumatoid arthritis patients. Strains from other arthritic conditions were included as controls. Evidence of the presence of a virus or viral information was sought by several methods of induction followed by ${ }^{3} \mathrm{H}$-uridine labelling and by assaying the culture supernatant for reverse transcriptase activity. In addition, various techniques of co-cultivation were tried in an attempt to rescue a defective virus. The DNA polymerase activity of the synovial cells was also assayed.

\section{Materials and methods}

SOURCE OF CELL STRAINS

The lining cells from synovial membranes obtained at synovectomy were dissected out and cut into small pieces. These were trypsinized $(0.25 \%$ trypsin in Dulbecco's solution) overnight at $37^{\circ} \mathrm{C}$ and the free cells removed into Eagle's complete medium containing $10 \%$ fetal calf serum. Monolayers of fibroblasts were passed by trypsinization. In addition, 4 strains grown out from explants of synovial tissue were received from Dr. D. Hamerman (A, B, C , and D). The synovial fibroblast strains used and the diagnosis of the patients from whom the specimens came are shown in Table I. The cell strains were tested at intervals for the presence of mycoplasmas as described previously (Mackay and others, 1974).

ULTRASTRUCTURE

Cells were harvested using glass beads and prepared for electron microscopy. In addition, cells were regrown for
Table I Source of synovial fibroblast strains

\begin{tabular}{ll}
\hline Strain & Diagnosis \\
\cline { 1 - 2 } A & RA \\
B & RA \\
C & Congenital hip displasia \\
D & Osteoarthrosis \\
E & RA \\
F & RA \\
G & Osteoarthrosis \\
H & RA \\
I & Polyarthritis (non-RA) \\
J & RA \\
K & Osteoarthrosis \\
L & Osteoarthrosis and Paget's disease \\
M & RA \\
N & Osteoarthrosis \\
\hline
\end{tabular}

3 days after storage in liquid nitrogen before being harvested for electron microscopy. The special glycogen stain of De Bruijin (1973) and Schaff, Barry, and Grimley (1973) was used on cell strain B. The blocks were sectioned on an LKB Ultratome 11 and the sections viewed on a Hitachi HU11A electron microscope.

GLUCOSE-6-PHOSPHATE DEHYDROGENASE ISOENZYME

The method of Ellis and Alperin (1972) was used.

\section{ATTEMPTS TO INDUCE VIRUS PRODUCTION}

\section{(A) Induction followed by ${ }^{3} \mathrm{H}$-uridine labelling}

Some of the cell strains were incubated in the presence of BUDR $(20 \mu \mathrm{g} / \mathrm{ml})$ for 3 days (Lowry and others, 1971), IUDR $(20 \mu \mathrm{g} / \mathrm{ml})$ for 3 days followed by dimethylsulphoxide (DMSO) $(2 \%)$ for 4 days (Stewart and others, 1972), cycloheximide $(10 \mu \mathrm{g} / \mathrm{ml})$ for 16 hours (Aaronson and Dunn, 1974), or with mitomycin $\mathrm{C}(1 \mu \mathrm{g} / \mathrm{ml})$ for 18 hours in the dark (Weiss and others, 1971).

The medium was replaced with the minimal volume of Eagle's medium containing $1 \%$ fetal calf serum and $\left(5-{ }^{3} \mathrm{H}\right)$ uridine $(2.5 \mu \mathrm{Ci} / \mathrm{ml}$, Amersham) and incubation continued for a further 24 hours. Ammonium sulphate precipitation of the culture supernatant was carried out according to the method of Grayzel (1973). The precipitate was dissolved in $1 \mathrm{ml} 0.01 \mathrm{~mol} / 1$ TRIS- $\mathrm{HCl}, 1 \mathrm{mmol} / 1$ EDTA pH 7.1, layered on the top of a linear sucrose gradient of 20 to $70 \%(w / v)$ sucrose in buffer, and spun at 24000 r.p.m. for 18 hours at $4^{\circ} \mathrm{C}$ in a SW 40 rotor. Fractions of about $0.5 \mathrm{ml}$ were collected from the bottom and their refractive index measured. $1 \mathrm{ml}$ cold $10 \%$ trichloracetic acid and $50 \mu 10.2 \%$ bovine serum albumin were added to each fraction and after at least 20 minutes at $4^{\circ} \mathrm{C}$ the precipitate was collected on glass fibre filter paper discs (Whatman GF/A), washed extensively with cold $10 \%$ TCA, followed by cold ethanol. They were air-dried and counted in PPO-toluene scintillator in a Packard Tri-Carb liquid scintillation instrument.

(B) Induction with testosterone and IUDR

The procedure of Holder, Robey, and Vande Woude (1974) was used. The cultures were incubated in the presence of testosterone acetate $(5 \mu \mathrm{g} / \mathrm{ml})$ for 8 weeks, being split as necessary, usually once every 2 weeks. The 
medium was changed weekly. The supernatant was collected at 2-week intervals and assayed for reverse transcriptase activity using the method of Lieber and others (1973). Finally IUDR $(100 \mu \mathrm{g} / \mathrm{ml})$ was added for 1 day before the final supernatant sample was collected.

\section{CO-CULTIVATION}

\section{(A) XC test}

The procedure of Rowe, Pugh, and Hartley (1970) was used.

\section{(B) With various cell lines}

The procedure outlined by Benveniste and others (1974) for inducing C-type virus from baboon placenta was used.

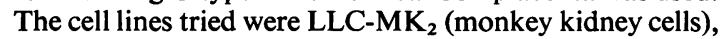
D-17 (dog fibrosarcoma cells), XC (rat tumour cells transformed by Prague strain of Rous sarcoma virus), 118 MG-EH (human glioma cells transformed by murine sarcoma virus), HT-1 (hamster cells transformed by murine sarcoma virus), and human fetal skin fibroblasts. $6 \times 10^{5}$ cells were seeded in a medical flat, incubated overnight, and induced with $30 \mu \mathrm{g} / \mathrm{ml}$ IUDR for 24 hours. $1 \times 10^{5}$ cells of the various lines were added and incubation continued for 8 weeks. Culture medium was changed weekly and the cultures were split at fortnightly intervals. The supernatant was assayed every 2 weeks for the presence of reverse transcriptase activity using the method of Lieber and others (1973).

\section{TRANSFECTION}

DNA was extracted from the cells using the method of Karpas and Milstein (1973) and Karpas and Tuckerman (1974). Human fetal skin fibroblasts were subsequently exposed to it. The cells were cultured in Eagle's medium containing $10 \%$ fetal calf serum and split at about 10-day intervals.

\section{DNA POLYMERASE ACTIVITY}

\section{(A) Culture supernatant}

Induction with BUDR or testosterone of the synovial cell strains was carried out as indicated previously, and $20 \mathrm{ml}$ culture fluid prepared and assayed according to the method of Lieber and others (1973).

\section{(B) Cells}

Synovial fibroblasts, grown in 4 or 5 Roux flasks, were washed in medium and prepared as outlined by Coffin and Temin (1971). Protein content was estimated by the method of Lowry and others (1951). Assays were carried out using the conditions in Norval and others (1975). The polymerase activity after preincubation with RNase, and its sensitivity to actinomycin $\mathrm{D}$ was determined.

\section{Results}

Of the 14 fibroblast cell strains used in the course of this work, all were free of mycoplasma contamination except cultures $\mathrm{A}$ and $\mathrm{C}$ which were found to contain Mycoplasma orale 1. Testing for the isoenzyme glucose-6-phosphate dehydrogenase showed that all cell strains possessed the slow (B) type compared to HeLa cells which have a fast (A) type.

\section{ULTRA STR UCTURE}

Ultrathin sections of the cells showed highly vacuolated cells with dilated endoplasmic reticulum, shown in Fig. 1. Synovial fibroblasts from rheumatoid sources could not be distinguished from the nonrheumatoid synovial fibroblasts. The cells had an increased lipid content after storage in liquid nitrogen for a period of time in medium containing $10 \%$ dimethylsulphoxide, followed by regrowth in normal medium; otherwise no difference in structure or growth could be detected. The only strain showing any abnormality was $\mathbf{B}$ and, in this case, the cells contained considerable deposits of glycogen granules (Fig. 2). These were identified using the special glycogen strain of De Bruijin (1973) at the electron microscope level and could be removed by preincubation with diastase. This material appeared to be very similar to that described previously in what was presumed to be a culture arising from accidental co-cultivation of Chang and synovial cells (Mackay and others, 1974). Strain B grew very slowly compared to the other cultures, although the rate could be increased by the addition of hyaluronidase ( 80 units/ml) to the culture medium.

\section{INDUCTION}

Several methods were tried to induce an RNA virus, should it be present, from the integrated state. These

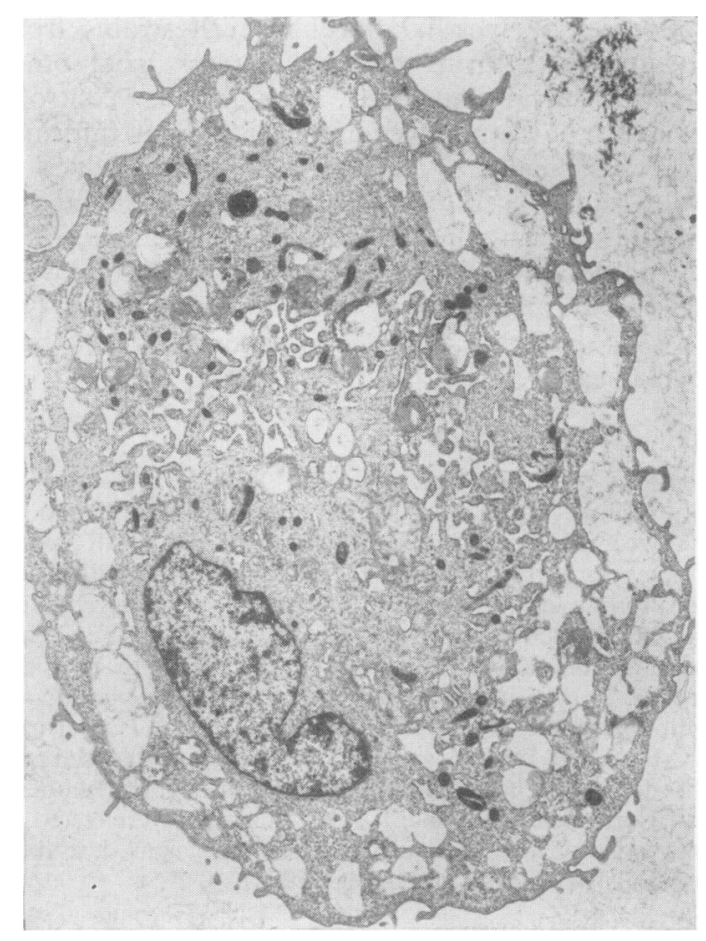

FIG. 1 Ultrathin section of synovial fibroblast from strain I. $(\times 3900)$ 


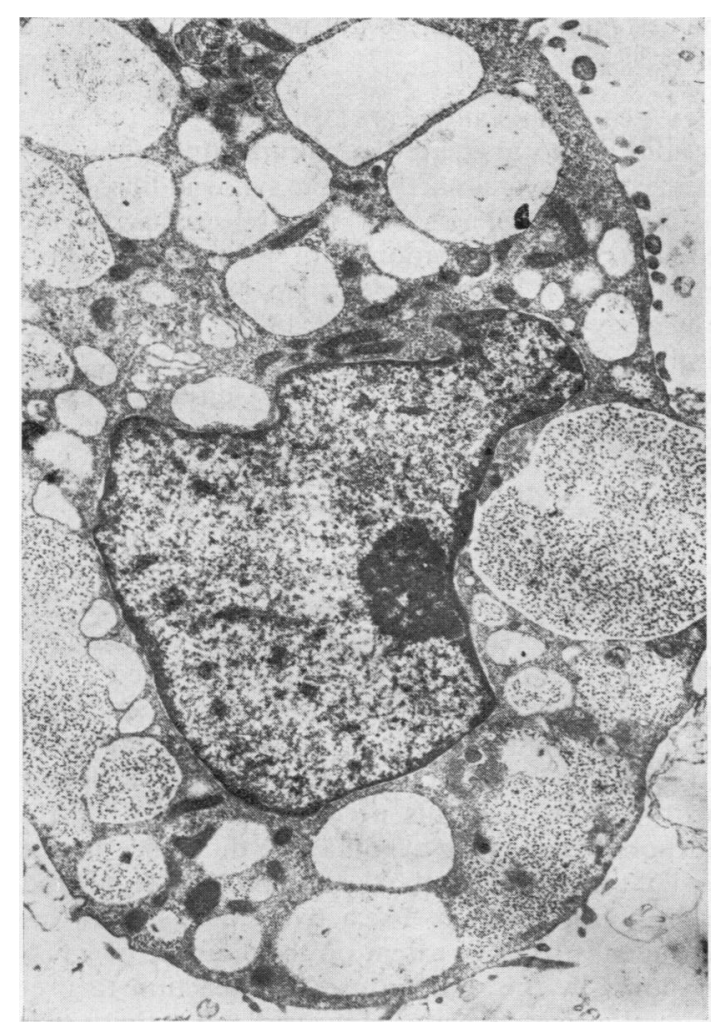

FIG. 2 Ultrathin section of synovial fibroblast from strain B. $(\times 660)$

methods depended on the use of various nucleic acid analogues such as IUDR, or protein inhibitors such as cycloheximide. Addition of the inducer to the medium was followed by labelling with ${ }^{3} \mathrm{H}$-uridine, which will be incorporated into the RNA of any virus being synthesized. The medium was then concentrated by ammonium sulphate precipitation and fractionation carried out by sucrose density gradient centrifugation. Leucoviruses typically have a density of $1 \cdot 16-1 \cdot 18 \mathrm{~g} / \mathrm{cm}^{3}$ under such conditions (Robinson, 1967), while that of mycoplasmas is around 1.22 (Todaro, Aaronson, and Rands, 1971). Table II shows the cell strains which were induced and the agents used.

In all cases there was no radioactivity in the region of the gradient where leucoviruses band. Fig. 3

Table II Methods of induction of synovial strains

\begin{tabular}{ll}
\hline Strain & Induction \\
\hline B, E, F, K, N & BUDR \\
A, C, F, I, N & IUDR + DMSO \\
D, E N & Cycloheximide \\
F, I, N $~$ & Mitomycin C \\
A, C, F, I, N & Testosterone \\
\hline
\end{tabular}

shows this result with strain $F$ induced with mitomycin $C$. With strains $A$ and $C$ induced with IUDR and DMSO, there was a peak of radioactivity at a density of 1.22, as shown in Fig. 4. As these cultures are known to be contaminated with mycoplasmas which have this particular density, the incorporation of ${ }^{3} \mathrm{H}$-uridine into acid-insoluble material seems likely to be into mycoplasma particles. As a positive control for this method of detecting RNA viruses, a culture of feline embryonic amniotic cells chronically infected with feline leukaemia virus was used. The virus particles had the appropriate density of $1 \cdot 17$ on the sucrose density gradient used.

In addition to the above methods, induction with testosterone was attempted using synovial cultures

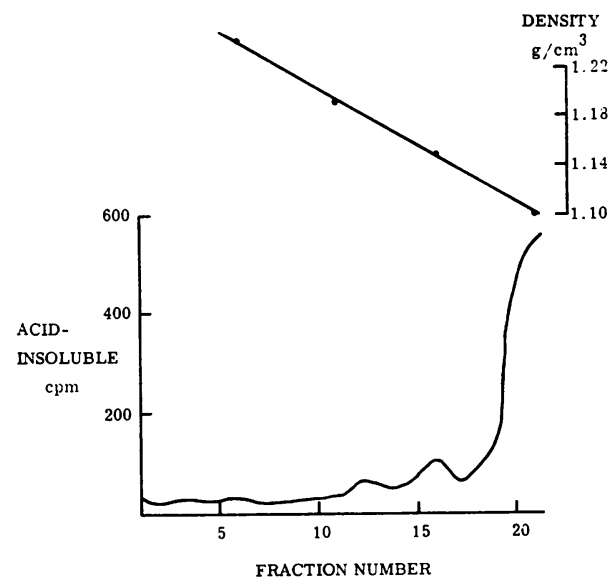

FIG. 3 Strain $F$, pass 7 (induced with mitomycin $C$ and labelled with ${ }^{3} \mathrm{H}$-uridine): acid-insoluble cpm in fractions from sucrose gradient

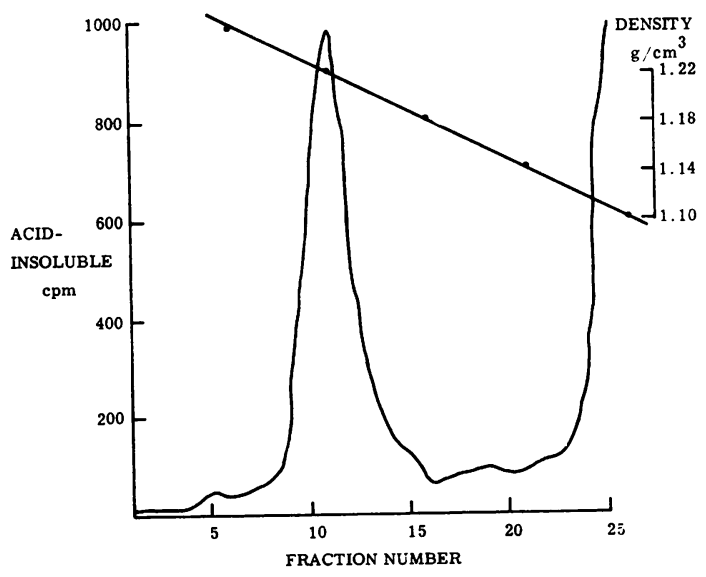

FIG. 4 Strain $A$, pass 12 (induced with IUDR and DMSO and labelled with ${ }^{3} \mathrm{H}$-uridine): acid-insoluble cpm in fractions from sucrose gradient 
A, D, F, I, and N. This was followed by assay of the culture supernatant for reverse transcriptase activity which would indicate release of leucovirus particles. Testosterone has been reported to induce C-type virus from the human carcinoma cell line HBT-3 after pretreatment with IUDR (Holder and others, 1974). With the synovial cells, testosterone was found to inhibit the growth of all the strains to some extent. The level used proved toxic for strain I, but the others were carried for the full 8-week period and showed no change in morphology as seen in the light microscope. At no time, except in the case of strain A, did the culture supernatant show any sign of DNA polymerase activity. With $\mathrm{A}$, there was a small increase in acid-precipitable counts over the 2-hour incubation period but this is probably accounted for by cell lysis and release of cellular DNA polymerase.

Induction of strains $\mathrm{E}, \mathrm{F}, \mathrm{K}$, and $\mathrm{N}$ with BUDR was also carried out, followed by assays of the culture supernatant for the presence of reverse transcriptase. Again no activity was detected.

\section{CO-CULTIVATION}

As an alternative to and in addition to induction of the synovial fibroblasts, various methods of cocultivation were tried. Cell lines from several sources were used in an attempt to discover one which may be permissive for a defective virus. In the first place an XC test was tried with synovial strains A, D, F, I, and N. It has been shown that plaques are formed when XC cells are placed in contact with cells infected with laboratory or field isolates of murine leukaemia virus (Rowe and others, 1970). However, when the synovial cells were tried in this test, no giant cells, syncytia, or plaques were formed in the cell sheet as demonstrable by light microscopy or haematoxylin staining.

In the second place, the method of Benveniste and others (1974) by which C-type particles were induced from baboon placenta was tried. In this case the synovial cells from strains $A, D, F, I$, and $N$ were induced for 24 hours with IUDR and co-cultivated with LLC-MK 2 , D-17, XC, 118 MG-EH, HT-1, and human fetal skin fibroblasts. These cell lines were also cultured alone. The culture supernatants were assayed for the presence of reverse transcriptase enzyme. After incubation for 1 week, the cell lines added to the synovial fibroblast cultures were the dominant cells in the co-cultivation. The assays for reverse transcriptase of both the co-cultivated cells and the cell lines showed a slight increase in acid-precipitable counts over the 2-hour incubation period but this is probably due to the presence of DNA polymerase released by cell lysis. The rate of incorporation of the supernatant from the cell lines alone was always the same as that when co-cultivated with the synovial fibroblasts. It was therefore concluded that no C-type particles had been induced by this method, or that the cell lines chosen were not permissive for such a virus.

\section{DNA POLYMERASE ACTIVITY}

In addition to assaying the culture supernatant for reverse transcriptase activity, the synovial fibroblasts themselves were assayed. The sensitivity of the reaction to preincubation with RNase was determined. Also it is necessary, as has been pointed out previously (Norval and others, 1975), to distinguish viral reverse transcriptase within the cells from normal RNA-primed but DNA-directed DNA polymerase. Here the distinction was made on the basis of sensitivity to actinomycin $\mathrm{D}$ as viral reverse transcriptase is unaffected by the presence of this antibiotic, while cellular DNA polymerase is inhibited (McDonnell and others, 1970). The strains used and the results obtained are shown in Table III. It may be seen that all strains showed endogenous DNA polymerase activity. This is expressed as an increase in acid-precipitable counts per minute over the first 30 minutes of the incubation per $\mu \mathrm{g}$ protein. An enzyme concentration which gives a linear incorporation over this period was chosen. There did not appear to be a noticeable difference in the level of this enzyme in the rheumatoid cells compared to the nonrheumatoid. The activity in all strains was dependent to a large extent on the presence of RNA as shown by the sensitivity of the reaction to preincubation with RNase. However, the activity was severely inhibited by actinomycin $\mathrm{D}$ in all cases, which may indicate that the polymerase is RNAprimed rather than RNA-directed and hence not viral in origin.

\section{TRANSFECTION}

As a final attempt to extract a possible viral genome from the synovial cells, a transfection experiment was carried out. DNA was extracted from strains C and $F$ and was used to 'infect' human fetal skin fibroblasts at a low pass. The cultures were split at about 10-day intervals and kept until the cells began

Table III DNA polymerase activity of synovial strains

\begin{tabular}{|c|c|c|c|}
\hline Strain & $\begin{array}{l}\text { Polymerase activity } \\
\text { (increase acid- } \\
\text { insoluble cpm in } \\
30 \text { min/ } \mu g \text { protein) }\end{array}$ & $\begin{array}{l}\text { Activity after } \\
\text { preincubation } \\
\text { with RNase }\end{array}$ & $\begin{array}{l}\text { Activity in } \\
\text { presence of } \\
\text { actinomycin } D\end{array}$ \\
\hline $\begin{array}{l}\mathbf{A} \\
\mathbf{D} \\
\mathbf{E} \\
\mathbf{F} \\
\mathbf{H} \\
\mathbf{J} \\
\mathbf{K} \\
\mathbf{L} \\
\mathbf{M} \\
\mathbf{N}\end{array}$ & $\begin{array}{l}4 \cdot 0 \\
4 \cdot 3 \\
9 \cdot 6 \\
2 \cdot 2 \\
0.9 \\
1 \cdot 8 \\
5 \cdot 6 \\
1 \cdot 7 \\
1 \cdot 6 \\
4 \cdot 8\end{array}$ & $\begin{array}{l}1 \cdot 0 \\
0 \cdot 3 \\
0 \cdot 25 \\
0 \\
0 \\
0 \\
0 \cdot 25 \\
0 \\
0 \\
0\end{array}$ & $\begin{array}{l}0 \\
0 \cdot 3 \\
\overline{0} \\
\overline{0 \cdot 4} \\
\overline{0 \cdot 2} \\
0 \\
0\end{array}$ \\
\hline
\end{tabular}


to die after about 8 months. There was no sign of transformation and no change in cell shape or growth in the DNA-infected cultures compared to the controls.

\section{Discussion}

The synovial fibroblasts described in this work were all used at as low a subculture as possible and normally under pass 12 . They began to die out around pass 18 . No difference could be detected in gross morphology between strains from rheumatoid and nonrheumatoid sources or in growth rate, except that the rheumatoid cells tended to be more spaced out, perhaps due to their increased hyaluronic acid content. Also, ultrastructural studies showed no apparent differences apart from one rheumatoid strain which had significant accumulations of glycogen granules. This strain grew very slowly compared with the others and the deposits may reflect some altered cellular metabolism, although it is interesting that such deposits have been reported in a line of hamster cells (HT-1) transformed by murine sarcoma virus (Karpas and others, 1971). They have also been shown in what was presumed to be a culture arising from accidental co-cultivation of Chang and synovial cells and details of this will shortly be published (M. Norval, A. Graham, and B. P. Marmion, unpublished).

Various attempts were made to rescue a defective or integrated RNA virus which might be present within the rheumatoid synovial cells and, in particular, techniques developed for leucovirus detection were used. Induction methods included addition of IUDR, a nucleic acid analogue; cycloheximide, a protein inhibitor; mitomycin C, a DNA inhibitor; and the hormone testosterone. After treatment with these compounds for varying lengths of time, the culture supernatant was tested for the presence of RNA viruses by ${ }^{3} \mathrm{H}$-uridine labelling, or for leucoviruses by reverse transcriptase assays. The culture supernatant from at least $5 \times 10^{6}$ synovial cells was used in the labelling experiments and was concentrated by ammonium sulphate precipitation before being layered on a sucrose density gradient. $20 \mathrm{ml}$ of culture supernatant was used in the reverse transcriptase assays and concentrated first by centrifugation through $20 \%$ glycerol according to the method of Lieber and others (1973). Sensitivity of the reaction was increased by the addition of polyadenylic aciddecathymidylic acid to the assay mixture. No positive results were obtained with any technique.

In addition to inducing the synovial fibroblasts, co-cultivation with a variety of cell lines was tried. It has been shown recently by Todaro and others (1974) that C-type viruses can be induced from several normal baboon tissues by co-cultivation with permissive host cell lines derived from a variety of mammalian species. They were not infectious for several baboon cell cultures. Thus it was decided to try co-cultivation of synovial fibroblasts with five cell lines from species other than man, plus human fetal skin fibroblasts. Some of the cell lines already contained part of a viral genome within the cells, such as the HT-1 cell line which consists of hamster cells transformed by murine sarcoma virus. It was thought that these might complement any viral information within the synovial cells. However all the co-cultivation methods failed to show the presence of a leucovirus or a cytopathic virus. Of course this does not mean that such a virus is definitely not present in an integrated form within the synovial cells as the methods of induction and co-cultivation may not be suitable for its expression, or the cell lines chosen may not be permissive.

Assays for DNA polymerase activity in the synovial cells failed to show the presence of viral reverse transcriptase. There was endogenous DNA polymerase activity which was shown to be RNase sensitive. However, it was strongly inhibited by actinomycin D which probably means that the enzyme is not viral in origin but is cellular RNAprimed DNA-directed polymerase. The cell lysate is a relatively crude preparation and it was found difficult to obtain sufficient cells at a low pass to try further experiments, such as the effect of various synthetic templates. However, the results obtained do corroborate the recent report of Spruance and others (1975) where cultured synovial cells from 8 patients with RA and 7 controls were examined for reverse transcriptase. On the basis of ability to utilize various synthetic templates, it was concluded that there was no viral reverse transcriptase present in any strain, and all the activity was due to DNAdirected polymerase. They reported a slightly increased level of cellular DNA polymerase in the rheumatoid cells compared to the nonrheumatoids. This was not found under the conditions used to assay this series of synovial strains, where no exogenous template was added. Again, finding no reverse transcriptase enzyme does not exclude the presence of a leucovirus genome from the synovial cells as this enzyme may not always be expressed or may not be detectable under the assay conditions used.

In a final attempt to rescue a leucovirus genome, the nuclear DNA from a rheumatoid and a nonrheumatoid strain was extracted and used in a transfection experiment with human fetal skin fibroblasts. Recently it has been shown that cellular transformation can be induced by viral-coded DNA, in particular DNA extracted from human rhabdomyosarcoma cells caused transformation of fetal skin fibroblasts (Karpas and Tuckerman, 1974). However, no transformation or change in cellular morphology took place over an 8-month period. 
An alternative approach is to look for viral-coded antigens on the cell surface and now the synovial strains are being examined for leucovirus groupspecific and interspecies antigens. Apart from infection with leucoviruses, the methods used would have detected a productive infection with rubella virus. In view of the results of Patterson, Howard, and Deinhardt (1973), the synovial fibroblast strains have also been examined for rubella virus antigens by immunofluorescence and by radioimmunoassay but with negative results so far $(\mathrm{H}$. Hart and B. P. Marmion, unpublished).
This work was supported by a grant from the Nuffield Foundation. We wish to acknowledge the help of Dr. M. Ogilvie and the consultant surgeons at the Princess Margaret Rose Hospital, Edinburgh, for providing the synovial membrane specimens. Synovial strains A, B, C, and $D$ were kindly provided by Dr. D. Hamerman and most of the remainder were first cultured at the Northern General Hospital by Mr. W. A. Neill. We thank Dr. J. L. Riggs for the D-17 cell line, Dr. A. Karpas for the HT-1 cell line, Dr. O. Jarrett for the XC cell line and the feline leukaemia virus, and Dr. J. Ponten for the 118 MG-EH cell line. We are very grateful for the help of Mrs. Alexia Graham in examining the ultrastructure of the synovial fibroblast cells.

\section{References}

Aaronson, S. A., AND DunN, C. Y. (1974) Science, 183, 422 (High-frequency C-type virus induction by inhibitors of protein synthesis)

Bartfield, H. (1965) Ann. rheum. Dis., 24, 31 (Rheumatoid arthritis and non-rheumatoid synovium in cell culture. Morphological observations, acridine orange, and fluorescent II studies)

Benveniste, R. E., Lieber, M. M., Livingston, D. M., Sherr, C. J., Todaro, G. J., and Katler, S. S. (1974) Nature, 248, 17 (Infectious C-type virus isolated from a baboon placenta)

Castor, C. W., AND Fries, F. F. (1961) J. Lab. clin. Med., 57, 394 (Composition and function of human synovial connective tissue cells measured in vitro)

Clarris, B. J., Fraser, J. R., And Rodda, S. J. (1974) Ann. rheum. Dis., 33, 240 (Effect of cell-bound hyaluronic acid on the infectivity of Newcastle disease virus for human synovial cells in vitro)

Coffin, J. M., AND Temin, H. M. (1971) J. Virol., 7, 625 (Comparison of Rous sarcoma virus specific deoxyribonucleic acid polymerases in virions of Rous sarcoma virus and in Rous sarcoma virus-infected chicken cells)

De BruiJin, W. C. (1973) J. Ultrastruct. Res., 42, 29 (Glycogen, its chemistry and morphological appearance in the electron microscope)

Ellis, N., AND Alperin, J. P. (1972) Amer. J. clin. Path., 57, 534 (A rapid method for electrophoresis of erythrocyte glucose-6-phosphate dehydrogenase on cellulose acetate plates)

ForD, D. K., AND OH, J. O. (1965) Arthr. and Rheum., 8, 1047 (Use of 'synovial' cell cultures in the search for a virus in rheumatoid arthritis)

GraYZeL, A. I. (1973) Ibid., 16, 419 (Uridine incorporation into the media and RNA of cultured rheumatoid synovial cells)

Holder, W. D., Robey, W. G., AND Vande Woude, G. F. (1974) Nature, 249, 759 (Activation of a C-type virus from the human carcinoma cell line HBT-3 by iododeoxyuridine and testosterone)

Ishimoto, N., Temin, H. M., ANd Strominger, J. L. (1966) J. biol. Chem., 241, 2052 (Studies of carcinogenesis by avian sarcoma viruses. II. Virus-induced increase in hyaluronic acid synthetase in chicken fibroblasts)

KarPas, A., AND MilsteIn, C. (1973) Europ. J. Cancer, 9, 295 (Recovery of the genome of murine sarcoma virus (MSV) after infection of cells with nuclear DNA from MSV transformed non-virus producing cells)

- - AND TUCKERMAN, E. (1974) Lancet, 1, 1138 (Transformation of human fibroblasts with DNA of cultured human rhabdomyosarcoma cells)

- Cawley, J., Tuckerman, E., Fleymans, R., and Hayhoe, F. G. (1971) Brit. J. Cancer, 25, 779 (Cytochemistry, cytogenetics and ultrastructure of hamster tumour cells carrying mouse sarcoma viral genome (HT-1 cells))

Lieber, M. M., Benveniste, R. E., Livingston, D. M., and Todaro, G. J. (1973) Science, 182, 56 (Mammalian cells in culture frequently release type $C$ virus)

Lowry, D. R., RoWe, W. P., Teich, N., AND HaRtley, J. W. (1971) Ibid., 174, 155 (Murine leukaemia virus: high frequency activation in vitro by 5-iododeoxyuridine and 5-bromodeoxyuridine)

Lowry, O. H., Rosebrough, N. J., Farr, A. L., and Randall, R. J. (1951) J. biol. Chem., 193, 265 (Protein measurement with the Folin phenol reagent)

McDonnell, J. P., Garapin, A. C., Levinson, W. E., Quintrell, N., Fanshier, L., AND Bishop, J. M. (1970) Nature, 228, 433 (DNA polymerases of Rous sarcoma virus: delineation of 2 reactions with actinomycin D)

Mackay, J. M., Norval, M., Robinson, A., Tait, D., Hart, H., Marmion, B. P., Muir, A., and Neill, W. A. (1974) Ann. rheum. Dis., 33, 453 (Cytology of rheumatoid synovial cells in culture. III. Significance of isolates of epithelial cell lines)

Norval, M., OGilvie, M., ANd Marmion, B. P. (1975) Ibid., 34, 205 (DNA polymerase activity in rheumatoid synovial membranes)

Patterson, R. L., Howard, F., and Deinhardt, F. (1973) Clin. Res., 21, 878 (Rubella virus and rheumatoid arthritis)

, Peterson, D. A., Deinhardt, F., And Howard, F. (1975) Proc. Soc. exp. Biol., 149, 594 (Rubella and rheumatoid arthritis: hyaluronic acid and susceptibility of cultured rheumatoid synovial cells to viruses) 
Person, D. A., Sharp, J. T., AND Rawls, W. E. (1973) Arthr. and Rheum., 16, 677 (Attempts to identify viruses and mycoplasmas in connective tissue diseases)

PhIllips, P. E. (1971) J. exp. Med., 134, 3138 (Virologic studies in rheumatoid arthritis and other connective tissue diseases)

RobINSON, H. L. (1967) Proc. nat. Acad. Sci. (Wash.), 57, 1655 (Isolation of non-infectious particles containing Rous sarcoma virus RNA from the medium of Rous sarcoma virus-transformed non-producer cells)

Rowe, W. P., Pugh, W. E., AND HaRTley, J. W. (1970) Virology, 42, 1136 (Plaque assay techniques for murine leukaemia viruses)

SChAFF, Z., BARRY, D. W., AND Grimley, P. M. (1973) Lab. Invest., 29, 577 (Cytochemistry of tubuloreticular structures in lymphocytes from patients with systemic lupus erythrematosus and in cultured human lymphoid cells)

SмIтH, C. A. (1971) J. exp. Med., 134, 306 S (Properties of synovial cells in culture)

Smith, C., AND HAMERMAN, D. (1969) Arthr. and Rheum., 12, 639 (Significance of persistent differences between normal and rheumatoid synovial membrane cells in culture)

- - (1974) Ann. rheum. Dis., 33, 180 (Virus resistance transferred from human rheumatoid to rabbit synovial cells. II. Cell fusion)

- - - J J J IS, R., AND HABERMANN, E. (1974) Ibid., 33, 173 (Virus resistance transferred from human rheumatoid to rabbit synovial cells. I. Methods and results of intra-articular injection of human cells into rabbit joints)

Spruance, S. L., Richards, O. C., Smith, C. B., AND Ward, J. R. (1975) Arthr. and Rheum., 18, 229 (DNA polymerase activity of cultured rheumatoid synovial cells)

Stewart, S. E., Karnie, G., Draycott, C., AND Ben, T. (1972) Science, 175, 198 (Activation of viruses in human tumours by 5 -iododeoxyuridine and dimethylsulfoxide)

Todaro, G. J., Aaronson, S. A., AND Rands, E. (1971) Exp. Cell Res., 65, 256 (Rapid detection of mycoplasmainfected cell cultures)

—, Sherr, C. J., Benvenisti, R. E., Lieber, M. M., ANd Melnick, J. L. (1974) Cell, 2, 55 (Type C virus of baboons: isolation from normal cell culture)

Weiss, R. A., Fries, R. R., KATZ, E., AND VoGt, P. K. (1971) Virology, 46, 920 (Induction of avian tumour viruses in normal cells by physical and chemical carcinogens)

WYNNE-ROBERTS, C. R., AND CASTOR, C. W. (1972) Arthr. and Rheum., 15, 65 (Ultrastructural comparison of rheumatoid and non-rheumatoid synovial fibroblasts grown in tissue culture) 